\title{
Accommodating Fun at Work Environment to Improve Employees Engagement
}

\author{
Cahyo Aji Nugroho ${ }^{1}$ and Erma Suryani ${ }^{2}$ \\ ${ }^{1}$ Department of Technology Management, Institut Teknologi Sepuluh Nopember, Surabaya \\ ${ }^{2}$ Department of Information System, Institut Teknologi Sepuluh Nopember, Surabaya \\ e-mail: cahyoaji.hkepc@gmail.com
}

\begin{abstract}
In companies' work of world nowadays, employees' psychological connection with their work has gained critical importance. In this context, companies not only must recruit the top talent, but must also inspire and enable employees to apply their full capabilities to their work by conditioning supportive working environment called fun at work. Grati Project, PT. Hutama Karya (Persero) holds a big project engaged in Combine Cycle Power Plant (CCPP). As a project accommodating many employees, the company realizes some internal and external factors that potentially create distraction and disharmony fostering disengagement and disrupting its flow. Anticipating this condition, Grati Poject, PT. Hutama Karya (Persero) creates some forms of workplace fun offer individual employee enjoyment which stimulates greater overall engagement with the team and company itself. However, this has not been confirmed because there is no research in this project discussing about the implementation of fun at work in order to increase employee involvement in Grati Project PT. Hutama Karya (Persero). This research descriptive explorative aims to evaluate the implementation of fun at work in Grati Project PT. Hutama Karya (Persero) in order to increase employee work engagement and identify the obstacles/ problems in it. This research also reveals the efforts/ strategies taken by the company to maintain employee work involvement by implementing fun at work program. Method of data collection in this research use preliminary survey and main survey through web-based questionnaire, interview and observation. Method of data analysis use descriptive explorative gained from Miles \& Huberman interactive analysis which consist of: (1) Data Reduction, (2) Present Data, and (3) Taking and Testing Conclusion. Result of this research are implementation 4 (four) fun at work dimension (socializing at work, celebrating at work, personal freedoms, dan global fun at work) that its real make work environment become fun then automatically improve employee work involvement which consist of 3 (three) dimension of vigor, dedication and work absorption. Result of this research also indicate problem and effort to resolve in order to implementation fun at work to improve employee work involvement which consist of: a) technical factor, b) social external factor, c) financial factor, d) fast program schedule, e) employee discipline and integrity.
\end{abstract}

Keywords-Descriptive Explorative Research, Fun at Work, Work Engagement.

\section{INTRODUCTION}

$\mathrm{N}$ OWADAYS, in the context of companies' daily work of world, there are some factors affecting employees to work optimally. One of them is a pleasant atmosphere at work. This atmosphere is very necessary for employees who work in places with a level of saturation and a high level of stress like working on a project within the company. The Grati Project is one of the major projects of PT Hutama Karya (Persero) which is located in Grati, Lekok, Pasuruan, East Java. The amount of employee in this project is considered big enough. This project is also characterized with the typical characteristics of the construction project which also has a high level of saturation and stress. Some examples of saturation factor in work on the Grati project are such as limited project work duration, erractic working hours, overtime work hours, multi-disciplinary project covering civil, mechanical, and electrical engineering's, high potential of social conflicts with external parties like the community around the project, technical factors- delayed project logistics, financial factors, and employee discipline and integrity. Moreover, about the deadline project, if the deadline of a certain project passes, the company will be charged a late fee in which its value is very expensive. It becomes worse it can be financially detrimental to the company. Concerning challenging situation described above, the company takes an effort to provide nicer atmosphere in order to increase the employees' work engagement so that the employees' performance in performing their duties and work can be as good as possible. According Eric and Michael D, 2009 [1]. One of the factors that is popular creating a comfortable environment and fun atmosphere is fun at work. Fun at work is an act of socialization, personal relations, entertainment, and excitement in the company.

\section{METHODS}

This research is descriptive explorative since it is still at the stage of "identification" for analyzing only to some descriptions or present the data system so that it can be more easily understood and concluded. The source of research data is using primary data or directly obtained data by the researcher. Besides, method for data collection in this research are through observation, interviews, and sample survey methods (survey that is only takes up most of the population because the total population of working on this project amounted to 70 people while respondents in this research were 40 people) The instruments used are in the form of a questionnaire, observation checklist, and interview guidelines. Talking about questioner, the researcher spreads the instruments to the sample through a web-based format called google form web-based questioner. Method of data analysis is using Miles and Huberman interactive data 


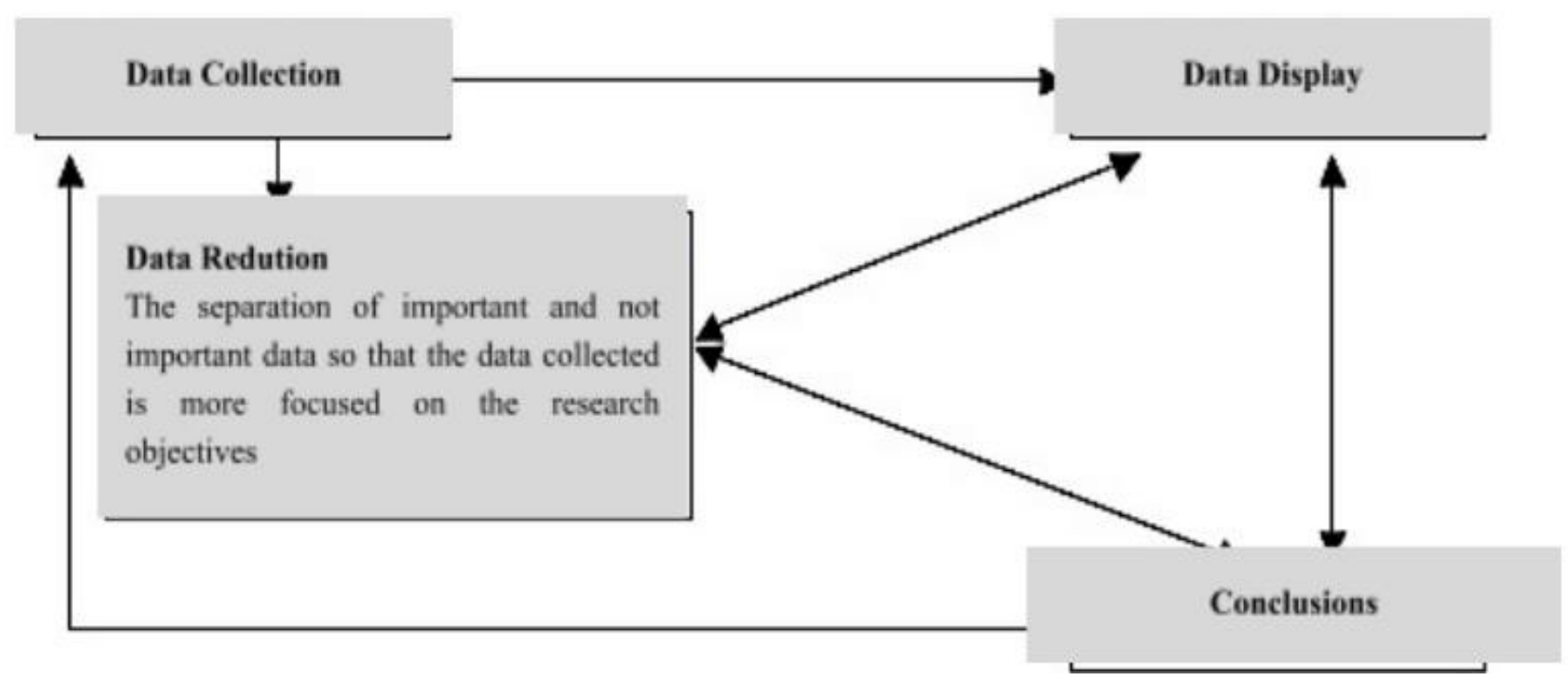

Figure 1. Analysis Method by Miles and Hubberman.

Table 1.

Total Respondents Based on Permanent or Contract Employee

\begin{tabular}{clcc}
\hline \hline No. & \multicolumn{1}{c}{ Status Employee } & Number of Respondents & Percentage \\
\hline 1 & Permanent Employee (min 6 months) & 20 & $50 \%$ \\
2 & Contract Employee (min 6 months) & $50 \%$ & 20 \\
\hline & Total & 40 & \\
\hline \hline
\end{tabular}

Table 2.

Total Respondents Based on Units/ Sections

\begin{tabular}{clcc}
\hline \hline No. & & Unit / Sections & Number of Respondents \\
\hline 1 & Engineering & 10 & Percentage \\
2 & Procurement & $25 \%$ & 6 \\
3 & Construction & $15 \%$ & 3 \\
4 & Human Resource \& General Affair & $35 \%$ & 14 \\
5 & Health, Safety Environment & $15 \%$ & $10 \%$ \\
\hline & Total & 40 & $100 \%$ \\
\hline \hline
\end{tabular}

Table 3.

Interview Question

\begin{tabular}{ll}
\hline \hline Question in the Interview \\
\hline 1 & What obstacles do you encounter in the Grati Project which can disrupt work conditions and reduce your work involvement? \\
2 & What effect do you feel from the obstacle you mentioned in Number 1? \\
3 & What solutions did the company try to overcome the obstacle that you mentioned in Number 1? \\
\hline \hline
\end{tabular}

analysis covering data reduction, data display, and verification activities.

\section{RESULTS AND DISCUSSION}

Respondents who followed the main survey in this research are employees of PT. Hutama Karya (Persero) who works on the selected Grati project through the purposive sampling method with the following criteria:

1. Permanent or contract employee (with minimum work period of 6 months) which having good integrity to the company.

2. Units/ sections of the project, that respondents are divided into Engineering, Procurement, Construction, Human Resource \& General Affair, and the Health, Safety Environment Officer / HSE

3. Respondents are working as contractor or subcontractor under on this company.

Referring to the above criteria of purposive sampling method that total sample as respondents are 40 people, herewith below summary characteristics of respondents in detail at Table 1 and Table 2.

\section{A. Data Collection Methods}

1) Main Web-Based Questionnaire with Variable Fun at Work \& Work Engagement

This method is main respondent completed questionnaires using web-based questionnaire for variable fun at work (with four-dimensional) \& work engagement (with threedimensional). For each variable fun at work and work engagement, its instrument consists of 30 items (statements) that is already tested in preliminary survey on expert judgement. In this case [2-4], measured the scale of fun at work using four-dimensional, such as Socializing at Work, Celebrating at Work, Personal Freedoms, and Global Fun at Work. Similar with fun at work dimensional the above, that this research is also measured the scale of work engagement by using three-dimensional, such as Vigor, Dedication and 
Table 4.

Observation Question

\begin{tabular}{ll}
\hline \hline Question in Observation \\
\hline 1 & How did the implementation of fun at work on the Grati Project working to increase engagement? \\
2 & What constraints are encountered in the Grati project which can disrupt the work atmosphere thereby reducing employee work involvement? \\
3 & What effect are experienced employees of the obstacles that arise which can disturb the working atmosphere thus decreasing employee \\
& $\begin{array}{l}\text { engagement? } \\
\text { What solutions company strived to overcome these obstacles? }\end{array}$ \\
\hline \hline
\end{tabular}

Table 5 .

Summary Number of Sample Respondents for each Categories

\begin{tabular}{|c|c|c|}
\hline No & er of Sample Respondents & Percentage \\
\hline 1 & 32 people & $80 \%$ \\
\hline 2 & Moderate & $20 \%$ \\
\hline \multicolumn{3}{|c|}{$\begin{array}{l}\text { Table } 6 . \\
\text { Summary of Fun at Work Item (Statement) with Positive Response }\end{array}$} \\
\hline $\begin{array}{l}\text { Dimension of Fun At } \\
\text { Work }\end{array}$ & Statement & $\begin{array}{l}\text { Positive } \\
\text { Response }\end{array}$ \\
\hline Socializing at Work & $\begin{array}{l}\text { 1. When interacting with colleagues at an intense time, I indirectly make friends } \\
\text { 2. During breaks, I exchange stories with co-workers } \\
\text { 3. I often joke with colleagues when on the sidelines of work } \\
\text { 4. At lunchtime, I exchange and share food } \\
\text { 5. Every day I go and go to work with my colleagues } \\
\text { 6. When worshiping in the office, I worship together with co-workers } \\
\text { 7. When my colleague's birthday gives me a congratulations } \\
\text { 8. I am always assisted and help co-workers when there are work difficulties }\end{array}$ & $\begin{array}{l}- \\
- \\
- \\
- \\
- \\
- \\
-\end{array}$ \\
\hline Celebrating at Work & $\begin{array}{l}\text { 9. Each year the company held a joint gathering and outbound employee } \\
\text { 10. Each is a special event, a celebration held office } \\
\text { 11. When I finish work faster than the specified time, the company rewards } \\
\text { 12. I participated in a farewell colleague event that was already complete } \\
\text { 13. I get a bonus during holidays and at the end of the year } \\
\text { 14. When I entered the company I was given rave reviews with good colleagues }\end{array}$ & $\begin{array}{l}\sqrt{ } \\
- \\
\sqrt{ } \\
- \\
\sqrt{ } \\
\sqrt{ }\end{array}$ \\
\hline Personal Freedoms & $\begin{array}{l}\text { 15. Every once in a week working time I wore casual clothes } \\
\text { 16. I am free to listen to music even in work hours } \\
\text { 17. When there is sudden business, I am allowed to go home first } \\
\text { 18. I often have lunch with colleagues during breaks } \\
\text { 19. At the time I was bored with my job, I try to amuse by playing games } \\
\text { 20. I perform worship on time during office hours } \\
\text { 21. I get additional leave at certain moments }\end{array}$ & $\begin{array}{l}\sqrt{ } \\
\sqrt{ } \\
- \\
- \\
- \\
\sqrt{ }\end{array}$ \\
\hline Global Fun at Work & $\begin{array}{l}\text { 22. I have flexible time at the office } \\
\text { 23. I don't feel bored while on a project } \\
\text { 24. When the boss looks pleasant working atmosphere becomes more comfortable } \\
\text { 25. My colleagues and I feel happy while working } \\
\text { 26. The atmosphere at the project office made me more excited to work } \\
\text { 27. I feel noticed when my boss encourages pleasure at work } \\
\text { 28. The project office I have a comfortable atmosphere to work } \\
\text { 29. I have productive colleagues in supporting the joint performance } \\
\text { 30. I get complete facilities from the project from food, transportation to official residence }\end{array}$ & $\begin{array}{l}- \\
- \\
- \\
- \\
- \\
\sqrt{ } \\
\sqrt{ } \\
\sqrt{ } \\
\sqrt{ }\end{array}$ \\
\hline
\end{tabular}

Absorption. And then, using Likert scale method, the researcher sets 4 (four) options which is very inappropriate (Sangat Tidak Setuju/STS), not suitable (Tidak Setuju/TS), suitable (Setuju/S), very appropriate (Sangat Setuju/SS) as the option for all item (statements) of the questionnaire for the main survey. These two questionnaires are used to know the implementation of fun at work to improve employee work engagement at the Grati Project PT Hutama Karya (Persero).

\section{2) Interview}

Interview is prepared to confirm the implementation of fun at work to improve employees' work engagement in the Grati Project PT Hutama Karya (Persero). In general, this interview contains 3 basic questions which will be asked to the respondents in Table 3.

\section{3) Observation}

Observation is conducted to capture the implementation of fun at work to improve employee work engagement in Grati
Project PT Hutama Karya (Persero) and also obstacle to be solved. This observation generally contains four fundamental questions in Table 4.

\section{B) Data Analysis Methods}

Qualitative data analysis by Miles and Huberman according to went through stages following organizing data, sorting them into units which can be managed to synthesize seek, finding patterns, identifying what is important and what is learned and deciding what can be told to others can be seen in figure 1 [5].

In detail Miles and Hubberman explained that because of this, three types of data analysis activities and data collection itself is a cyclical and interactive process. Three types of activities are:

\section{1) Data Reduction}

Data collection process to clarify the data obtained and 
The $6^{\text {th }}$ International Seminar on Science and Technology (ISST) 2020

July $25^{\text {th }} 2020$, Institut Teknologi Sepuluh Nopember, Surabaya, Indonesia

Table 7.

Summary Number of Sample Respondents for each Categories

\begin{tabular}{cccc}
\hline \hline No & Number of Sample Respondents & Categories & Percentage \\
\hline 1 & 32 people & Good & $90 \%$ \\
2 & 8 people & Moderate & $10 \%$ \\
\hline \hline
\end{tabular}

Table 8.

Summary of Fun at Work Item (Statement) with Positive Response

\begin{tabular}{|c|c|c|}
\hline $\begin{array}{l}\text { Dimension of Work } \\
\text { Engagement }\end{array}$ & Statement & $\begin{array}{l}\text { Positive } \\
\text { Response }\end{array}$ \\
\hline \multirow[t]{10}{*}{ Vigor } & I was excited when I come work together with others & - \\
\hline & 2. I always get excited when resting and eating together & - \\
\hline & 3. I never give up easily when facing problems together at site project & $\sqrt{ }$ \\
\hline & 4. I don't give up in facing challenges when I get an award & - \\
\hline & 5. I am more diligent in working when getting a bonus & $\sqrt{ }$ \\
\hline & 6. I want to try to help finish the work of my friends in the field to reach the target & $\sqrt{ }$ \\
\hline & 7. I am not easily discouraged in completing work according to deadlines & - \\
\hline & $\begin{array}{l}\text { 8. I am interested in attending morning exercises and tool box meetings every morning on } \\
\text { the project }\end{array}$ & $\sqrt{ }$ \\
\hline & 9. I am happy when the leave schedule is approved by boss & $\sqrt{ }$ \\
\hline & 10. I feel strong and powerful when working at the beginning of time & - \\
\hline \multirow[t]{10}{*}{ Dedication } & 11. I am always enthusiastic for attending meetings together & $\sqrt{ }$ \\
\hline & 12. I am proud if I can finish work in the field earlier than the deadline & - \\
\hline & 13. I feel inspired by a compact and solid work culture on the project & $\sqrt{ }$ \\
\hline & 14. I am challenged to start work on time & - \\
\hline & 15. I feel happy to carry out the duties and responsibilities together with others & $\sqrt{ }$ \\
\hline & 16. I don't want to leave work when my friends are still working at site & - \\
\hline & 17. I want to be a part of the success of the project and the company & - \\
\hline & 18. I give high priority to the deadlines for work to be completed in the project & $\sqrt{ }$ \\
\hline & 19. When I wake up in the morning I feel I have to go to work & $\sqrt{ }$ \\
\hline & 20. I can work for whole of day on a project & - \\
\hline \multirow[t]{10}{*}{ Absorption } & 21. I get carried away at work so time passes very quickly & $\sqrt{ }$ \\
\hline & 22. I feel happy working on the project because friends give attention to one another & $\sqrt{ }$ \\
\hline & 23. I am so absorbed in work that I forget everything else around & - \\
\hline & 24. I find it hard to separate myself from work because of the award given by the company & . \\
\hline & 25. I am happy to work when the work is done & $\sqrt{ }$ \\
\hline & 26. I can't leave my routine activities on the project even if something problem happen & - \\
\hline & 27. I concentrate fully on completing the given work targets & $\sqrt{ }$ \\
\hline & 28. I feel comfortable with work so I never bored on the site & - \\
\hline & 29. When I work I merge with my own work & $\sqrt{ }$ \\
\hline & 30. I enjoy my work even far from my family & - \\
\hline
\end{tabular}

facilitate further research in data collection, then the data reduction or selection process is carried out, focusing on simplification, abstraction, and transformation of raw data that emerged from notes that appeared in the field. This transformation process continues until the final report of the research is complete.

\section{2) Presentation of Data (Data Display)}

A collection of information arranged that gives possibilities to their conclusion and taking action. In this research, data presentation is done in the form of narrative text as stated by Miles and Huberman, "the most frequent form display data for qualitative research data in the past has been narrative text".

\section{3) Verification / Conclusion}

This stage researchers began searching for the meaning of relationships, noted regularity, patterns, and conclude. The basic assumptions and initial conclusions put forward still temporary and will change for as long the data collection process is still ongoing. However, if the conclusion is supported by valid and consistent evidence (data) that researchers find in the field, the conclusions put forward are credible. Data obtained through questionnaires are grouped into the following categories:
1. Good Category with a value of $76 \%-100 \%$;

2. Moderate Category $60 \%-75 \%$;

3. Less Categories 26\% -59\%.

The above of 3 (three) categories was arranged based on percentage accumulation in each answer of item (statement) at web-based questionnaire after conversion using the Likert scale method. Good Category with a value of $76 \%-100 \%$ mean that minimum $73 \%$ answer from sample respondents promote justification for good implementation fun at work to improve work engagement. Moderate Category 60\% -75\% mean that minimum $53 \%$ answer from sample respondents promote justification for moderate implementation fun at work to improve work engagement. And, Less Categories $26 \%-59 \%$ mean that less than $53 \%$ answer from sample respondents only promote justification for less implementation fun at work to improve work engagement. With variable of fun at work point of view in Table 5 and Table 6 shows the number of samples from 32 respondents with a Good Category rating which is $80 \%$ and 8 respondents with the Moderate Category rating which is $20 \%$.

With variable of work engagement point of view in Table 7 and Table 8 shows the number of samples from 36 respondents with a Good Category rating which is $90 \%$ and 4 respondents with the Moderate Category rating which is $10 \%$. 
The $6^{\text {th }}$ International Seminar on Science and Technology (ISST) 2020

July $25^{\text {th }} 2020$, Institut Teknologi Sepuluh Nopember, Surabaya, Indonesia

Table 9.

Summary of Fun at Work Item (Statement) with Positive Response

\begin{tabular}{|c|c|c|c|c|}
\hline No & Factor & Obstacle & Management Guideline & Solution \\
\hline 1 & Technical & $\begin{array}{l}\text { Construction delay } \\
\text { and delivery } \\
\text { material problem }\end{array}$ & $\begin{array}{l}\text { Company should meet with budget, } \\
\text { quality and schedule }\end{array}$ & $\begin{array}{l}\text { a. Make sure to make good coordination with } \\
\text { logistic and construction team } \\
\text { b. Intent to make good communication with Vendor }\end{array}$ \\
\hline 2 & Social External & $\begin{array}{l}\text { Conflict with social } \\
\text { external }\end{array}$ & $\begin{array}{l}\text { Implementation Company Social } \\
\text { Responsibility (CSR) }\end{array}$ & $\begin{array}{l}\text { a. Manage the participation of local residents to } \\
\text { work on the project } \\
\text { b. Socialization to local residents in a good way and } \\
\text { support the project }\end{array}$ \\
\hline 3 & Financial & $\begin{array}{l}\text { Delay of cash in } \\
\text { project }\end{array}$ & $\begin{array}{l}\text { Company should open with financial } \\
\text { condition }\end{array}$ & a. Managing back up cash in project \\
\hline 4 & Fast Program & $\begin{array}{l}\text { Fast program to } \\
\text { meet schedule }\end{array}$ & $\begin{array}{l}\text { Company should meet with budget, } \\
\text { quality and schedule }\end{array}$ & $\begin{array}{l}\text { a. Managing shift personnel and overtime working } \\
\text { b. Additional bonus to create enthusiasm }\end{array}$ \\
\hline 5 & $\begin{array}{l}\text { Discipline and } \\
\text { Integrity }\end{array}$ & $\begin{array}{l}\text { Lack of employee } \\
\text { discipline and } \\
\text { integrity }\end{array}$ & $\begin{array}{l}\text { Company values: integrity, } \\
\text { professional, customer focus }\end{array}$ & $\begin{array}{l}\text { a. Giving reward \& punishment, outbound, } \\
\text { employee gathering } \\
\text { b. Briefing and praying before starting work and } \\
\text { after finishing work to evaluate performance }\end{array}$ \\
\hline
\end{tabular}

In connection with the results of this study and in line with the vision of PT. Hutama Kaya (Persero) namely "Indonesia most valuable infrastructure developer", and the mission of PT. Hutama Kaya (Persero), namely "Building sustainable corporate capacity and capability through strengthening human capital and financial capital, and creating a safety culture within the company", then the following in Table 9 is the effort of PT. Hutama Karya (Persero) to overcome from obstacle that could hinder the implementation of fun at work in order to improve employee work engagement in the Grati Project PT. Hutama Karya (Persero) with refer to the result of interview and observation.

\section{CONCLUSION}

Realization four-dimensional of fun at work (socializing at work, celebrating at work, personal freedoms, and global fun at work) formed a fun working atmosphere improving employee work engagement. In more detailed portrait, the employees show a sense of enthusiasm, good dedication and absorption of work. In other words, the implementation of fun at work in the Grati Project of PT Hutama Karya (Persero) is very influential and improves employee work engagement. This study also wants to underline the managerial implications, that to increase employee work engagement which includes high working morale, good work dedication and maximum absorption of work activities, the company must ensure that the 4 dimensions fun at work should be implemented well in daily operations and interaction on the project environment. In detail, the pleasant working environment referred to here is that which supports: a) socialization between superiors and workers or between workers, b) appreciation of shared communal activities and individual achievement, c) respect for the existence and uniqueness of individuals, and d) a sense of comfort felt in the heart and confirmed by logic.

\section{RECOMMENDATION}

The results of this study are expected to provide benefits for management of the company as a basis for consideration in increasing the pleasure of working in their organizations. The examples of things needed by the company to increase fun (fun at work) at work to improve employee work engagement. At the time of the data collection process such as web-based questionnaire, interview, and observationon, expected to consider the circle circumstances (circumstances, mood, and time) respondents thus build a better emotional connection with respondents that research results be more valid.

\section{ACKNOWLEDGEMENT}

The writers wish to express their sincere gratitude to Grati Project of PT. Hutama Karya (Persero) and Department of Management Technology, Faculty of Creative Design and Digital Business - Institut Teknologi Sepuluh Nopember (ITS) for support provided for the research project on which this paper is based.

\section{REFERENCES}

[1] Lamm, Eric and Meeks, Michael D, "Workplace fun: the moderating effects of rational difference", Employee Relations, Vol. 31 Iss 6, pp. $613-631$

[2] McDowell T, "Fun at work: scale development, confirmatory factor analysis, and links to organizational outcomes", Doctoral dissertation, Alliant International University, Alhambra, CA, Dissertation Abstracts International, Vol. 65, p. 6697, 2004.

[3] Fluegge E.R., "Play hard, work hard, fun at work and job performance, Management Research Review”, Vol. 37 Iss 8, pp. 682 - 705, 2014.

[4] Jamaludin, M., F; Ahmad, A,M; Mohammad, A; Shobri, N.,D.,M., “ $A$ Study on the Relationship Between Fun at Work and Work Engagement. Proceedings of the ASEAN Entrepreneurship Conference. Safaria, Siti. 2013. Pengaruh Keterlibatan Kerja Terhadap Kinerja Pegawai pada PT Seascape Surveys Indonesia. Ejurnal Manajemen dan Bisnis", Vol. 1 No. 1. 2014.

[5] Pawito. Penelitian Komunikasi Kualitatif. Yogyakarta: LKiS Yogyakarta, 2008. 